\title{
Finance as a Competitiveness Factor in Mexican Beef Industry
}

\author{
Antonio Emmanuel Perez Brito, María Marlene Martín Méndez, Karla Patricia Quintal \\ Gordillo
}

Universidad Autonoma de Yucatan, Mexico

*Corresponding Author: Antonio Emmanuel Perez Brito, Universidad Autonoma de Yucatan, Mexico

\begin{abstract}
This paper's objective is to show that finance could be considered as a factor of competitiveness with regard to the analysis as suggested by David (2003), which is based on the use of financial information; the criterion of Sallenave (1994) and Gitman (1986), who consider profitability and funding as components. Owners of 30 cattle ranches were included in the state surveys, with each ranch having at least 1,000 head of cattle. The study was quantitative, and used a multiple linear regression model. The results were that the use of financial information, the profitability and funding are components of finance factor, being the profitability, relatively more important.
\end{abstract}

Keywords: Finance, Competitiveness, Bovine Livestock Industry, Mexican

\section{INTRODUCTION}

Meat consumption is considered to be influenced by income levels, and thus is an indicator of economic prosperity (OECD\& FAO, 2009).

According to the Food and Agriculture Organization of the United Nations (FAO, 2013), livestock accounts for 40 per cent of the global value of agricultural production, and forms the basis of livelihood and food security for nearly a billion people.

Gonzalez (2006) mentioned that livestock-raising is undertaken throughout Mexico. He stated that 56 per cent approximately 110 million hectares) of the total area of the national territory is dedicated to this activity.

The System of National Accounts in Mexico, developed by the National Institute of Statistics and Geography (INEGI, 2010), noted that Yucatan's agricultural and fisheries sectors constitute 6.7 per cent of the total Gross Domestic Product (GDP) of Mexico.

According to Anderson, Santos, Boden, and Wadsworth (2012) cattle-raising is a significant economic activity in Yucatan, because it is undertaken in about 30 per cent of the total Yucatecan territory. They also suggest that the area to the east of Yucatan recorded the highest number of beef cattle.

The agricultural sector in Yucatan faces several challenges: disorganization of beef producers in the region; problems in the integration of the various links in the production-consumption chain (Hernandez, Rebollar, Gonzalez, Guzman, Albarran \& Garcia, 2011); unemployment resulting from the few job opportunities that result in labor migration to other regions (Martinez, Santos \& Montes, 2012); value-generation for all activities; and finally, limited financial resources (Vera \& Ganga, 2007).

The XIII General Census of Population and Housing (INEGI, 2010), also reports that the per capita income is low, since among the total employed population. For this reason, the region east of Yucatan is regarded as having extreme marginalization.

An important business market to be considered due to its proximity to Yucatan is the state of Quintana Roo. Information obtained from the Secretariat of Economy (SE, 2009), indicates that this neighboring state helps cater to the increasing demand for agricultural and livestock products of neighboring areas, as the growing tourist industry and demography render domestic production insufficient to satisfy the demand by itself. 
This research thus aims to identify if finance could be considered as a factor of competitiveness of the livestock industry of Yucatan.

\section{LITERATURE REVIEW}

\subsection{Competitiveness}

According to the approach of classical economic theory, Smith (1776) notes that the key to social welfare lies in economic growth, which is founded through division of labor (specialization), resulting in the generation of economies of scale and differences in productivity across nations. He further states that capital investment (improving the machinery) and trade (increasing market size) facilitate this specialization, thus increase productivity that leads to economic growth. However, this growth must be reinforced to generate a greater division of labor, and eventually maintain continuous growth.

Keynes (1936) differs in many important points with regard to the classical economic theory, primarily regarding the functioning of markets. Another important difference is in his vision of capital and labor.

Hamel, Doz and Prahalad (1989) point out that, in the short term, competitiveness among companies is determined by the quality and performance of their products or services. However, in the long term, the ability of companies to build and improve their core competencies, such as those skills that create distinctive new generations of products or services, is more important.

Grant (1991) suggests the presence of other factors in addition to those proposed by Porter (1990), (innovation in products and processes), to upgrade or maintain competitive advantage, such as financial capabilities and marketing strategies, among others.

According to Dussauge, Hart and Ramanantsoa (1992), technological changes can affect competition in virtually any activity. Technology has an impact on competitiveness because it affects either differentiation or the cost; these are the two generic fundamental strategies for competitiveness.

Rueda and Simon (2002) pointed out that the competitiveness is increasingly dependent on the manner in which the economic agents are organized into networks of companies that cooperate and compete among themselves. Agricultural activity is not exempt from being immersed in the process of globalization.

Pohl (2007) suggested that focusing on the discovery of new talent, identifying new roles of finance in business, and creating new benchmarks by financial managers will allow companies to be more competitive in the existing market.

Perea and Rivas (2008), in a study on the competitiveness of the coffee industry in Veracruz, suggested that the factors having the greatest impact on competitiveness include-innovation, marketing, and finance.

\subsection{Finance as a Competitiveness Factor}

Gitman (1986) mentioned that financial resources are instrumental in maintaining the solvency of a company in terms of provision of cash flows required to satisfy obligations, and acquire the current assets required to achieve the company's goals, thereby improving competitiveness. To provide financial resources, measurement of firms' profitability and funding is needed.

Companies have many goals, but according to Sallenave (1994, p. 86-101), it can be reduced to three: profitability, growth, and survival.

Birley and Westhead (1990) point out that the maintenance of good financial standards through proper financial management is one of the main factors highlighted as necessary to achieve competitive success. In this regard, it is necessary to be cautious in short-term planning, in deploying and managing information systems, in paying special attention to credit institutions, in establishing annual budgets, in conducting analysis of the economic and financial situation, and in striving to be selfsufficient in sources of financing.

Competitive strategy in the area of finance involves establishing a "functional strategy" to deal with questions related to the use and application of resources, and organizing the capabilities or skills within the financial area. This is undertaken to maximize the productivity of resources (Manguzzato, 
1991) to assist in the attainment of the desired competitive advantage, and thereby to achieve the degree of competitiveness of the company (Claver, 1995)

According to David (2003, p. 281-287), the use of financial information is essential in the development and deployment of strategies in organizations. He also points out that enterprises that apply the concepts of strategic management are more profitable and successful, record more sales, and reach higher levels of productivity and competitiveness than companies that do not apply these concepts.

Financial resources are necessary to develop the activities of other functional areas such as marketing, production, human resources, and sales. If the strategy to improve a company's competitiveness requires the acquisition of assets such as machinery or human resources, the department of finance should design a sustainable strategy. It is also necessary to be aware of the non-viability of objectives that may be set by other functional areas of the company(Bravo, 2010).

\subsection{The Beef Industry}

Laens and Paolino (2004) noted that the international beef market comprises a very small percentage of world production, since most beef is intended to supply the domestic market of producing countries. Overall, the percentage of production exported is just above $10 \%$. This leads to meat being produced with different characteristics in different countries according to the preferences of local consumers.

Although meat is a commodity that has little added value, it cannot really be considered a homogeneous product, due to variations based on origin and quality. On the one hand, the existence of health problems such as disease or bovine spongiform encephalopathy (BSE) has led to international market segmentation (aphthous BSE-free countries or affected countries). On the other hand, the product also differs according to the animal type (breed) or according to the production technology used (process innovation).

The United States Department of Agriculture (USDA, 2005) reported that world beef production is around 50 million tons annually. This figure has remained relatively stable since the early nineties, after a period of steady growth.

Beef cattle production is important in Mexico as it uses the natural resources of more than $50 \%$ of the national territory; beef contributes to the staple diet, it generates foreign exchange through the export of livestock, thus contributing to the national economy, and it also contributes to rural development by creating employment. The importance of this sector is not just related to the beef product, it also involves a set of resources associated with its operation. However, the inclusion of Mexico in today's global meat market is marginal, as the breeding and fattening of cattle in the national economy has shrunk due to an increase in imports of meat and meat derivatives.

A decline in the profitability of beef production in Mexico explains the current statistics of a large number of overdue loans; as a result, producers have left the sector or have lost some of their investment against the need to settle their claims. Many farmers are informal beef producers, lacking the equipment, technology, training, resources, and adequate infrastructure for the efficient and effective development and growth of livestock production (Chauvet, 2009).

According to SAGARPA (2012), beef production is of great economic importance in Mexico.

During the five years until 2010, the amount of dressed beef carcass had increased at an AAGR (average annual growth rate) of 2.3\% to reach 1.74 million tons in 2010, with a value of 57954 million pesos. Beef is the second most common meat, with the highest annual growth in volume after sheep meat in the given period. It also had the third highest annual growth in value, with an average of $4.3 \%$ between 2005 and 2010, behind poultry meat and sheep meat at a beef sheep value of 60.761 million pesos. It is important to note that beef is the second highest domestic producer after poultry in Mexico, contributing 30.5\% of total production (SAGARPA, by its Spanish acronym, 2012).

According to the above-mentioned secretariat, Veracruz, Jalisco, Chiapas, Chihuahua, Baja California, Sinaloa, and Sonora account for $51.7 \%$ of the beef produced in Mexico. The remaining $48.3 \%$ is divided between all states of the country. 
Based on the information obtained from SAGARPA (2012), Mexican households spend $22.7 \%$ of their disposable income on food. Of this expenditure, one in three Mexican pesos is used to buy livestock products (poultry, turkey, pork, beef, lamb, and goat). In Mexico about 1.9 million tons of beef is consumed annually, which means a per capita consumption close to $17 \mathrm{~kg}$. The country is a net importer of beef, with a deficit estimated at 578 million dollars in 2011, equivalent to 138 thousand tons of meat.

Similarly, although it is increasing, the proportion of Yucatan livestock production in the national total is quite low and has been at this level for over 25 years.

Várguez (2013) notes that the most important livestock capital is in the hands of private producers, whose ranches hold most of the national herd. In 2013, the value of livestock production was more than two billion pesos. Cattle production is dominated by Yucatecan entrepreneurs and the average size of individual farms is not very large, usually between 1000 and 5000 hectares, although some farmers have many ranches. The largest farms are in the east (the Tizimin area); however, despite having the largest ranches, they lack the technology to streamline their processes and they do not have marketing plans, new product development, or the financial resources to survive. There are also major problems in obtaining credit to allow them to access new markets.

\section{MATERIALS AND METHOdS}

Quantitative research was used in this study and used a multiple linear regression model. For determining the finance competitiveness index, research was undertaken with information obtained from the large cattle ranches (having at least 1,000 head of cattle) of Yucatan in 2013. We conducted a survey specifically designed to gather the information necessary for this analysis, which was obtained from the owners of the ranches. The results were obtained through the application of the statistical package IBM SPSS Statistics 21.

Based on the data provided by the Union Regional livestock of the East of Yucatan (UGROY, by its Spanish acronym, 2013), the population is composed of 30 big ranches in Yucatan. In this case, it could access all observation units that integrate into the target population.

We revised the validity and reliability of the instrument applied to obtain the information, mainly through exhaustive review of related literature, review by experts (content validity), construct validity through implementation of factorial analysis, and finally reliability analysis of the instrument through Cronbach's alpha coefficient. In both cases the results were satisfactory.

For this study, finance will be considered a factor of competitiveness with regard to the analysis as suggested by David (2003), which is based on the use of financial information; the criterion of Sallenave (1994) and Gitman (1986), who consider profitability and funding as variables

\section{RESUltS AND DISCUSSION}

To analyze the relationship between the components of the finance factor we conducted a multiple linear regression model, reviewing the compliance of the assumptions of the built models, the standardized regression coefficients, and the p-values associated with these coefficients in such models.

Based on this information and considering the value of the standardized regression coefficients as a measure of the relative importance that the aspects of finance section saved in relation to the competitiveness of the observation units, as well as the p-values from the tests of statistical significance for the regression coefficients object of study, the following results can be concluded:

With regard to finance factor, the more related aspects are the sources of funding, the use of financial information, and profitability, which coincides with the fact established by David (2003), Gitman (1986) and Sallenave (1994), being the profitability the most importante component.

The correlation between the finance components is tested through the correlation coefficients calculated, generating the following equation:

Finance: $\mathrm{y}=0.269 \times 1+0.515 \times 2+0.461 \times 3-7.209$ 


\section{CONCLUSiOnS}

The sample used for the study comprised 18 cattle ranches in the municipality of Tizimin (60 per cent), five in the municipality of Panaba (16.7 per cent), three in the municipality of Sucila (10 per cent), and the rest include ranches in the municipalities of Buctzotz, Cenotillo, Dzilam Gonzalez, and Sotuta.

1. Ranches have an average age of 31 years, with an average of 27 full-time workers working in them. The ranches have an average of 1.120 heads of cattle, and a territorial extension of 1.306 hectares. Finally, it was found that owners are on average 57 years of age.

2. The most important component is the profitability.

3. Finance are a factor of competitiveness for this economic sector.

Our study is unique because the results obtained have important practical implications for the sector. The livestock industry in Yucatán represents one of the main strategic activities of the state but faces a serious problem of competitiveness. A more competitive livestock sector would lead to improved economic growth, sustainable human development, and social integration. Economic and environmental improvement involves the creation of economic value in a way that also generates a shared value for society.

In this regard, it is suggested that the finance competitiveness model should be created in other important strategic sectors in the state of Yucatán, such as manufacturing, tourism, and other parts of the agricultural sector. Furthermore, this study can be used in other states that may also propose the finance competitiveness model.

The current study contributes to existing literature on the beef industry on Mexican ranches, and it informs the administrators and/or owners about the weaknesses to be overcome in order to become more competitive. This study could also orient owners to enable them to adopt strategic models and methodologies that will boost the competitiveness of the sector, as well as to generate value-added products, thereby ensuring their position in competitive markets. The study could further enable the Mexican government to understand the challenges faced by the livestock industry, and the related support available through public policies, such as generating sources of wealth and employment, to contribute towards gaining more access to sources of funding for new investments. This study could be beneficial for institutions of higher education for incorporation into programs of study including the linkage programs and continuing education on topics related to strategic cattle management. Most importantly, it aims to continue promotion of the generation and application of innovative knowledge, through professors, researchers, groups, and/or research networks, in the region, the nation, and internationally. Within Research limitations/implications, it is worth noting the context in which this information can be applied.

\section{REFERENCES}

[1] Anderson, S., Santos, J., Boden, R., \& Wadsworth, J. (2012). Characterization of cattle production systems in the state of Yucatan. Dual purpose cattle production research. Fundación Internacional para la Ciencia, 40[2], 187-192.

[2] Birley, S., and Westhead, P. (1990), Growth and performance contrasts between types of small firms, Strategic Management Journal, No.11, pp. 535-557

[3] Bravo, M. (2010), Introducción a lasfinanzas. México, Pearson.

[4] Chauvet, M. (2013), La Ganadería Bovina de Carne en México. Del Auge a la Crisis. México. UAM

[5] Claver, E. (1995), Manual de administración de empresas.España, Civitas.

[6] David, F. (2003). Conceptos de administración estratégica (Ninth edition). México: Pearson.

[7] Dussauge, P., Hart, S., and Ramanantsoa, B. (1992), Strategic technology management. England, John Wiley \& Sons Ltd

[8] Gitman, L. (1986). Fundamentos de administración financiera. México: Editorial Harla.

[9] González, E., (2006). La sanidad y el estado sanitario del hato nacional de bovinos para carne. CONASA.

[10] Grant, R. (1991), Porter's competitive advantage of nations: An assessment. Strategic Management Journal,Vol.12 No1, pp.535-548

[11] Hamel, G., Doz, Y., and Prahalad, C. (1989), Collaborate with your competitors and win. Harvard Business Review, Vol. 2 No.1, pp.133-139. 
[12] Hernández, J., Rebollar, S., González, F., Guzmán, E., Albarrán, P., \& García, M. (2011). La cadena productiva de ganado bovino en el sur del estado de México. Revista Mexicana de Agronegocios, 29[15], 672-680.

[13] InstitutoNacional de Estadística y Geografía (INEGI, 2010). Censo de población y vivienda 2010. http://operativos.inegi.org.mx/sistemas/iter/entidad_indicador.aspx?ev=5. Retrieved on May 15, 2018.

[14] InstitutoNacional de Estadística y Geografía (2010). Sistema de cuentas nacionales de México. XIII Censo General de Población y Vivienda 2010. http://www.inegi.org.mx/est/contenidos/proyectos/ccpv/cpv2010/ presentacion.asp. Retrieved on May 22, 2018.

[15] Keynes, J. (1936), The general theory of employment, interest and money. England, Macmillan Cambridge University Press.

[16] Laens S. and Paolino C. (2004),Estudio de competitividad de cadenasagroindustriales: cadena carne vacuna. Uruguay. ECA

[17] Martínez, V., Santos, J., \& Montes, R. (2012). Función de producción de la ganadería de doble propósito de la zona oriente del estado de Yucatán.Técnica Pecuaria en México, 40[2], 187-192.

[18] Manguzzato, M. (1991), La direcciónestratégica de la empresa. Un enfoqueinnovador del management. España, Ariel.

[19] OECD \& FAO (2009). OECD-FAO agricultural outlook 2009-2018. OECD publishing.

[20] Organización de lasNaciones Unidas para la Agricultura y la Alimentación (FAO, 2013). El Estado Mundial de la Agricultura y la Alimentación. http://www.fao.org/docrep/018/i3300e/i3300e00.htm. Retrieved on May 22, 2018.

[21] Perea, J., \& Rivas, L. (2008) Estrategias competitivas para los productores cafetaleros de la región de Cordova, Veracruz. Revista de la Facultad de Contaduría y Administración de la UNAM, 24, 9-33.

[22] Pohl, H. (2007). Building a competitive finance function: An executive roundtable. The McKinsey Quarterly, 10[3], 1-8.

[23] Rueda, I., \&Simón, N. (2002). Globalización y competitividad. La industriasiderúrgicaubicada en México. México: Editorial Porrúa.

[24] Secretaría de Agricultura, Ganadería, Desarrollo Rural, Pesca y Alimentación., (SAGARPA, 2012), "Situación Actual y Perspectiva de la Producción de Carne de Bovino en México". Coordinación General de Ganadería, available at: http://www.sagarpa.gob.mx/delegaciones/Jalisco/boletines/Paginas/B0502012. aspx. (Accessed May 15, 2018).

[25] Sallenave, J. (1994). La gerencia integral. Colombia: Grupo Editorial Norma.

[26] Secretaría de Economía. (S.E., 2009). Sectores agropecuarios. http//:www.economia.gob.mx. Retrieved on August 22, 2013.

[27] Smith, A. (1776), An inquiry into the nature and causes of the wealth of nations. England, W. Strahan and T. Cadell.

[28] United States Department of Agriculture (USDA, 2005), World Market and Trade Archives, available at: http:www.fas.usda.gov. (Accessed May 15, 2018).

[29] Unión Ganadera Regional del Oriente. (UGROY, 2013). Informe Anual. CECSA.

[30] Várguez L. (2013), Mérida: Algunosaspectos de sutransformación y perspectiva actual. México. UADY.

[31] Vera, J., \& Ganga, F. (2007). Los clústers industriales: Precisión conceptual y desarrollo teórico. Cuadernos de Administración, 20 (33), 303-323.

\section{AUTHOR'S BIOGRAPHY}

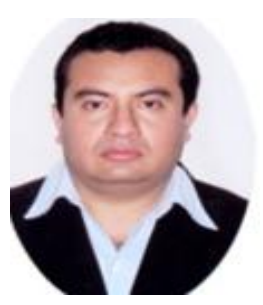

Antonio Emmanuel Perez Brito, Ph.D. from Universidad Popular Autonoma del Estado de Puebla (August 2014), is Professor of Finance at the Facultad de Contaduria y Administracion of the Universidad Autonoma de Yucatan. Current research interestsinclude regional development and competitiveness.Member of Sistema Nacional de Investigadores.

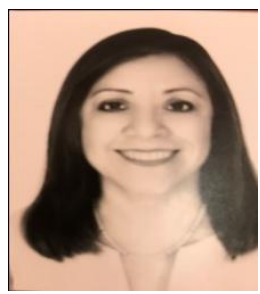

Maria Marlene Martin Mendez, Ph.D., from Universidad Autonoma de Yucatan (November 2017), is Professor of Cost Accounting at the Facultad de Contaduria y Administracion of the Universidad Autonoma de Yucatan. Current research interestsinclude management, organizational changeand social impact, regional development and competitiveness. 


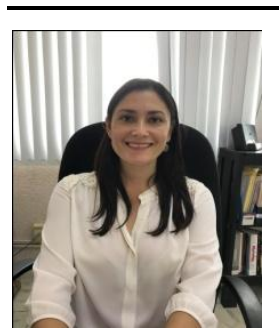

Karla Patricia Quintal Gordillo, Master in Business., from Universidad Tec Milenio (December, 2016), is professor of Marketing at the Facultad de Contaduria y Administracion of the Universidad Autonoma de Yucatan. Current research interestsinclude social marketing and competitiveness.

Citation: Antonio Emmanuel Perez Brito, et.al. “Finance as a Competitiveness Factor in Mexican Beef Industry" International Journal of Managerial Studies and Research (IJMSR), vol 6, no.6, 2018, pp. 9-15. doi:http://dx.doi.org/10.20431/2349-0349.0606002.

Copyright: () 2018 Authors. This is an open-access article distributed under the terms of the Creative Commons Attribution License, which permits unrestricted use, distribution, and reproduction in any medium, provided the original author and source are credited. 